\title{
The quality of EDIFACT referrals from primary care to the emergency department
}

\author{
Hanne Hestbech*, Søren W Hansen, Thomas A Schmidt \\ From Proceedings of the 5th Danish Emergency Medicine Conference \\ Aarhus, Denmark. 18-19 April 2013
}

\section{Background}

Communication between primary care and the Emergency Department is in most cases provided through written referrals. The quality is very important to create coherent clinical courses, treatment of high quality and high satisfaction among patients. 95\% of all admissions from primary care are delivered as EDIFACT, which is a secure way to send electronic post and to ensure immediate delivery. There's already a guideline that describes the requirements to EDIFACT admissions but no studies describe the quality and the use of them.

\section{Methods}

A retrospective study that included 228 patients admitted to the Emergency Department from primary care. We registered all admitted patients on 10 randomly selected weekdays in the period from the 1st of October to the 15th of December 2012. Only patients admitted from primary care via EDIFACT were included. All admissions have been thoroughly read and the content compared with the guideline.

\section{Results}

419 patients were admitted to the Emergency Department on 10 randomly selected days. Of these 419 patients 228 were admitted from primary care but only 140 (61\%) were referred by EDIFACT. All referrals (100\%) contained medical history, 16 admissions (11\%) contained information about allergies, 44 admissions (31\%) contained information about the patient's medication and 32 admissions (23\%) contained information about vital parametres.

\section{Conclusion}

It may be concluded that the quality of EDIFACT referrals from primary care varies a lot, but we also registered

\footnotetext{
* Correspondence: hanne@reupke.dk

The Emergency Department, Holbaek, University Hospital, Denmark
}

that the guideline isn't available for doctors in primary care. This isn't appropriate because important information about admitted patients is lost which results in poorer clinical courses. The 1st of January 2013 new and better guidelines are published which is a good possibility to clarify the importance of EDIFACT referrals. Because of time pressure in primary care one might consider the possibility of developing a new program in which information about the patient's medication and allergies are captured directly from the primary care charts. This might ensure that important information isn't lost when doctors in primary care are communicating with the Emergency Department.

Published: 9 September 2013

doi:10.1186/1757-7241-21-S2-A46

Cite this article as: Hestbech et al:: The quality of EDIFACT referrals from primary care to the emergency department. Scandinavian Journal of Trauma, Resuscitation and Emergency Medicine 2013 21(Suppl 2):A46.

Submit your next manuscript to BioMed Central and take full advantage of:

- Convenient online submission

- Thorough peer review

- No space constraints or color figure charges

- Immediate publication on acceptance

- Inclusion in PubMed, CAS, Scopus and Google Scholar

- Research which is freely available for redistribution

\section{Ciomed Central}

